\title{
Organic (Redox-Flow-)Batteries Using Compounds out of Bark and Peat as well as Humic Acids
}

\author{
Dominique Rosenberg*, Katharina Dick, Steffen Gudenschwager, Maike Busker, Walter Jansen \\ Chemistry and Chemistry Education, Institute of Mathematic, Scientific and Technical Literacy, \\ Europa-Universität Flensburg, Flensburg, Germany \\ *Corresponding author: Dominique.rosenberg@uni-flensburg.de
}

Received January 15, 2019; Revised March 02, 2019; Accepted April 02, 2019

\begin{abstract}
Redox-Flow-Batteries are currently being studied for the storage of wind and solar energy, especially the use of organic compounds as redox systems. With this communication we demonstrate, that these systems can be successfully used at school and in higher education. The focus is put upon the use of compounds found in bark and peat as well as humic acids.
\end{abstract}

Keywords: Redox-Flow-Batteries, renewable energy, organic batteries, natural products

Cite This Article: Dominique Rosenberg, Katharina Dick, Steffen Gudenschwager, Maike Busker, and Walter Jansen, "Organic (Redox-Flow-)Batteries Using Compounds out of Bark and Peat as well as Humic Acids." World Journal of Chemical Education, vol. 7, no. 2 (2019): 145-152. doi: 10.12691/wjce-7-2-14.

\section{Introduction}

A problem arises if wind and solar energy is used as source for renewable energy. There is little consumption of electrical energy during the time of highest energy generation and vice versa a high consumption during times with little energy generation. In order to compensate these contra cyclical fluctuations, there is a need for a reliable way to store electrical energy. That is the reason for the discussion about ways to store electrical energy in pumped storage plants, via electrolytic water splitting or the chemical storage in suitable accumulators $[1,2,3,4]$.

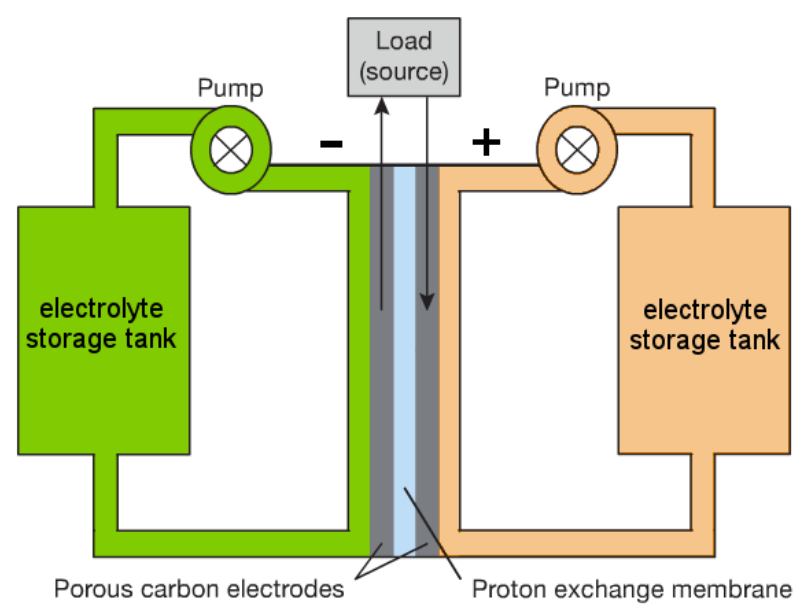

Figure 1. representation of a Redox-Flow-Battery according to [10,11]

Another way to store electrical energy currently being discussed is Redox-Flow-Batteries, which, in comparison to traditional batteries, should lead to a better material conversion. Redox-Flow-Batteries are galvanic cells, in which electrochemical active substances in aqueous solution are being circulated between carbon electrodes. If there is an excess of electrical energy present, these batteries can be charged and if necessary discharged thus releasing the stored energy. There exists a cycle for each half-cell, in which a suitable electrolyte circulates. The electrolyte storage tank serves as the reservoir for each electrolyte, which is pumped to the electrode surface in order for the electrochemical conversion to take place. The setting and overall function of such a Redox-FlowBattery is shown in Figure $1[3,4,5]$.

Substantial for the effectiveness of such a system is the used redox couple. Ion pairs of Vanadium in several oxidation states like $\mathrm{V}^{2+} / \mathrm{V}^{3+}$ and $\mathrm{VO}^{2+} / \mathrm{VO}_{2}{ }^{+}$have already been successfully tested for the use in Redox-FlowBatteries [5,6,7].

Such Redox-Flow-Batteries as a possible alternative energy storage have recently been installed and tested. In July 2015, a hybrid energy storage was put into operation in Braderup, on the west coast of Schleswig-Holstein (Germany), with a storage capacity of 3,4 MWh for a $18 \mathrm{MW}$ wind farm. The hybrid energy storage is composed of lithium ion batteries on the one hand and Redox-Flow-Batteries on the other hand, using a vanadium redox couple. Depending on the wind conditions, either the lithium batteries or the Redox-Flow-Batteries are charged [8]. Nowadays there are even reports about electric cars using Redox-Flow-Batteries [9].

Just as inorganic systems, organic redox systems can be used for Redox-Flow-Batteries. This was impressively demonstrated by M. J. Aziz $[10,11]$ und S. R. Narayanan [12], who used anthraquinone disulfonic acid and bromine or benzoquinone, respectively, to successfully operate a Redox-Flow-Battery with carbon electrodes. 
According to Aziz, the anthraquinone/anthrahydroquinone potential in sulfuric acid amounts to $+0,09 \mathrm{~V}$ and the bromine / bromide potential under standard conditions is $+1,09 \mathrm{~V}$ leading to a voltage of this electrochemical system of 1,0 V. Figure 2 shows the electrochemical reactions of the cell. Because of the rapid electrode reactions current densities from $0,95 \mathrm{~A} \cdot \mathrm{cm}^{-1}$ to $2,25 \mathrm{~A} \cdot \mathrm{cm}^{-}$ ${ }^{1}$ can be achieved. Moreover, this system exhibits a very good cycle stability with charging and discharging cycles having no effect on the voltage of the system, even slightly increasing the current density $[10,11]$.

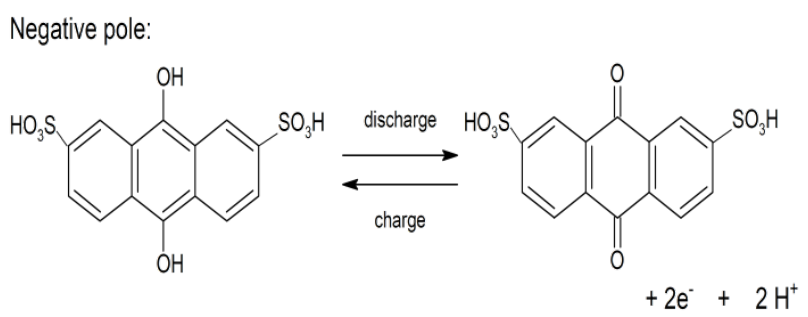

Positive pole:

$$
\mathrm{Br}_{2}+2 \mathrm{e}^{-}+2 \mathrm{H}^{+} \underset{\text { charge }}{\stackrel{\text { discharge }}{\rightleftarrows}} \quad 2 \mathrm{HBr}
$$

Figure 2. reactions at the electrodes in a semi organic Redox-FlowBattery according to M. Aziz [10]

Narayanan et al. used 1,2-benzoquinone-3,5-disulfonic acid instead of bromine as cathodic system. This compound exhibits a high positive potential in sulfuric acid of $+0,85 \mathrm{~V}$, leading to a voltage of the system 1,2-benzoquinone-3,5-disulfonic acid and anthraquinone disulfonic acid, of $0,74 \mathrm{~V}$. The rechargeability and cycle stability of these redox couples is at approx. $100 \%$. Figure 3 shows the reactions at the electrodes of the half-cells [12].

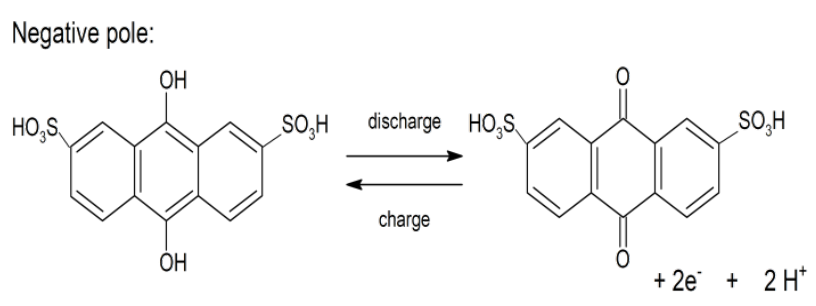

Positive pole:

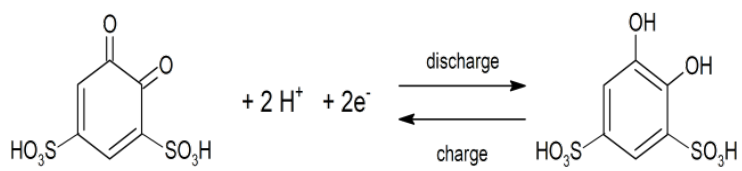

Figure 3. reactions at the electrodes in a semi organic Redox-FlowBattery according to S. R. Narayanan [12]

Recent communications of Schubert et al. [13], demonstrated the possible application of colloidal polymers with oxidisable or reducible substituents. They could be converted in sodium chloride solution with simple membranes on simple carbon electrodes. Terminal ammonium groups lead to a good solubility in water of the relative short polymers with molar masses around 20000
Dalton. A large scale plant in salt caverns, in Jemgum, Lower Saxony in northern Germany, with an energy storage of approx. $700 \mathrm{MWh}$ is currently under construction by EWE, an energy supplier in northern Germany.

Redox-Flow-Cells, as described in literature [6,7,10,11,12] are not commercially available. Therefore, some simple settings and several organic substances are given for the demonstration of the principle of Redox-Flow-Cells in the following article. In our previous communications $[14,15,16,17]$ we showed that Alizarin, Gallic acid, Henna red, Paracetamol and many more can be used as anodic material for organic batteries. Green tea and the flavoring substance Vanillin can be likewise electrochemically oxidized $[18,19]$. The focus of this communication will be on the use of compounds found in bark and peat as well as humic acid, which can be used at school and in higher education.

\section{Model Experiments for Organic Batteries}

The general setup of the experiments is shown in Figure 4. For the reaction of oxygen and electrochemical generated bromine out of bromide, the carbon-electrode according to Oetken [20] is used. For this, a sieve shell of a building's supplies store is filled with charcoal (grain size 1-3 mm, Carl Roth, Art.-Nr.: 5966.2, for e. g.). A thin compact charcoal electrode or a graphite pencil lead is used as a pick-up electrode.

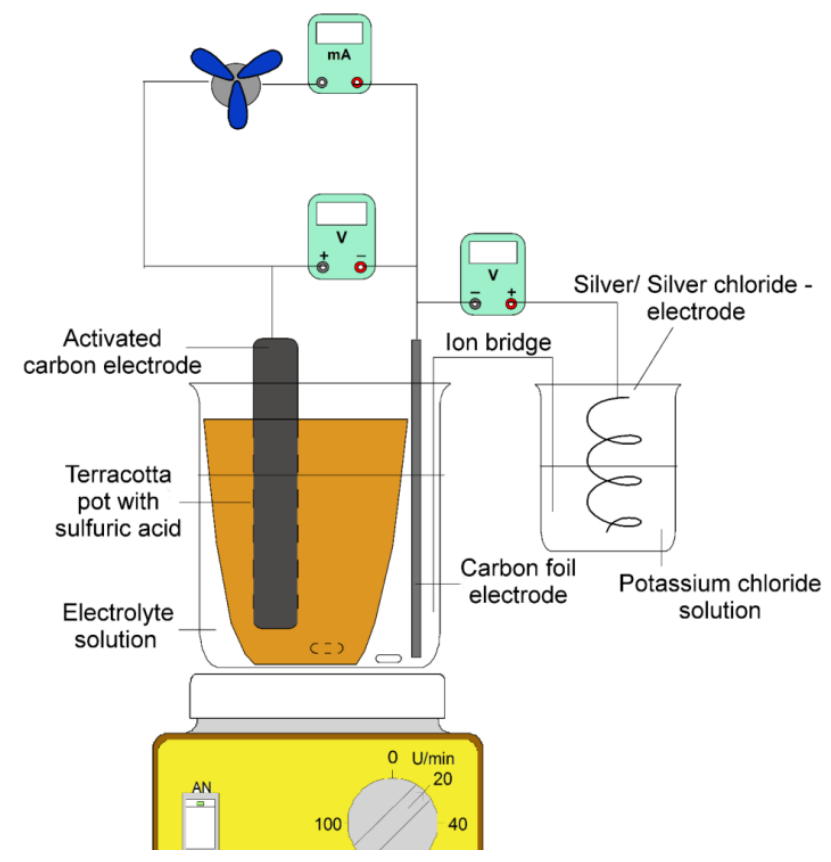

Figure 4. experimental setup for the experiments

As an effective diaphragm, an earthenware pot is used, whose underside is sealed via a rubber plug. With the experiments in [21], it is shown that a good ion conductivity is ensured, while preventing the mixture of the anodic and cathodic electrolyte. Thus, an alkaline solution can be used outside the pot while inside the pot, an acidic solution is used. The pot is put into a wide $600 \mathrm{~mL}$ beaker. 
Table 1. Sources of the used equipment

\begin{tabular}{|l|c|c|c|c|}
\hline & Merchant & Article No. & Dimensions & Price \\
\hline Sieve Shell & Building's supplies store & -------- & $\begin{array}{c}\emptyset=16 \mathrm{~mm} \\
1=5 \mathrm{~mm}\end{array}$ & 4 pcs. for $2,65 €$ \\
\hline $\begin{array}{l}\text { Compact charcoal electrode } \\
\text { Pencil Lead }\end{array}$ & $\begin{array}{c}\text { www.eydam.de } \\
\text { Faber-Castell }\end{array}$ & $\begin{array}{c}139098010 \\
\text { TK } 9071\end{array}$ & $\begin{array}{c}100 \times 6 \mathrm{~mm} \\
\varnothing=65 \mathrm{~mm}\end{array}$ & $\begin{array}{c}2,80 € \text { per pc. } \\
6,00 € \text { for } 10 \text { pcs. }\end{array}$ \\
\hline Graphite foil & www.conrad.de & 189060 & $190 \times 190 \times 0,2 \mathrm{~mm}$ & $5,99 €$ pro pcs. \\
\hline Digital multi-meter & www.conrad.de & $1090519-62$ & & $19,99 €$ per pc. \\
\hline Terra-cotta pot & hardware store & ----- & $\begin{array}{l}\emptyset=65 \mathrm{~mm} \\
\mathrm{~h}=80 \mathrm{~mm}\end{array}$ & $0,79 €$ per pc. \\
\hline Powerful elektric motor & www.dreibeingmbh.de (only on request) & H60-0047 & & $20,00 €$ per pc. \\
\hline Sensitive electric motor & www.lemo-solar.de & SMM502 & & $47,90 €$ per pc. \\
\hline Beaker, wide & www.carlroth.de & C116.1 & $600 \mathrm{ml}$ & 10 pcs. for $66,40 €$ \\
\hline
\end{tabular}

Graphite foils of the company Conrad are used, but can be replaced by the carbon felts of the company SGL Carbon. A silver/silver chloride electrode is used to determine the electrode potential. This electrode can either be bought or be made by oneself [22] out of silver wire. The flow is maintained via a magnetic stirrer and a magnetic stirring bar in the beaker as well as in the pot.

We already described experiments for school according to AZIZ and NARAYANAN [23]. The system Gallic acid in sodium hydroxide solution and p-benzoquinone in a mixture of glacial acetic acid and sulfuric acid can be recommended for school classes because of the simple molecular structure. The oxidation and reduction of quinones and hydroquinones, respectively, can easily be demonstrated and explained. Firstly, we will focus on organic batteries using the bark of oak and ash trees in this communication.

\section{Experiments with Bark}

The bark of oak trees is rich in tannins, which are not only used as tanning agents but also for the improvement of wines. For the experiments two years stored oak bark was used.

\subsection{Experiments with Bark}

Used Equipment: Beakers (600 mL and $100 \mathrm{~mL})$, terracotta pot, underside sealed with a rubber plug, carbon foil (approx. $3 \mathrm{~cm} \times 4 \mathrm{~cm}$ ), carbon/oxygen-electrode according to Oetken [20], silver/silverchloride electrode, sensitive electric motor (LemoSolar), powerful electric motor (Dreibein Lehrsysteme), 4 multimeters, magnetic stirrer with stirring bars, stand material, wires with crocodile clip

Chemicals: Oak bark, sodium hydroxide solution $\mathrm{c}(\mathrm{NaOH})$ $=1 \mathrm{~mol} / \mathrm{L}$, sulfuric acid $\mathrm{c}\left(\mathrm{H}_{2} \mathrm{SO}_{4}\right)=1 \mathrm{~mol} / \mathrm{L}$, glacial acetic acid, potassium chloride solution $(\mathrm{KCl})=1 \mathrm{~mol} / \mathrm{L}$

Procedure: $30 \mathrm{~g}$ fragmented oak bark is heated for approx. 10 minutes in the beaker with $300 \mathrm{~mL}$ of sodium hydroxide solution. The solution will turn deep brown and is then transferred into a $600 \mathrm{~mL}$ beaker (wide) for decantation and the carbon foil will be put into it. The terracotta pot is filled with sulfuric acid and the carbon/oxygen-electrode according to Oetken [20] is put into it.

In order to stabilize the potential, 3-5 $\mathrm{g}$ of sodium peroxodisulfate can be added, which will decompose gradually into hydrogen peroxide and oxygen, without influencing the potential. The electrode potential is determined via a silver/silver chloride electrode in a small beaker filled with potassium chloride solution using an, in potassium chloride solution immersed filter paper, as an ion bridge between the small and the large beaker. The resulting experimental setup is shown in Figure 4.

The voltage of the battery is at $1,49 \mathrm{~V}$ after 5 minutes.

The resting potential of the carbon/oxygen-electrode is at $+1,30 \mathrm{~V}$ and the oak bark extract / graphite electrode at $-0,19 \mathrm{~V}$. A sensitive electric motor can be operated with a current consumption of $3 \mathrm{~mA}$ without problems. The voltage stays stable at $1,27 \mathrm{~V}$ during the 30 minute measurement. The potential of the carbon/oxygenelectrode drops slightly while the potential of the oak bark extract / graphite electrode rises to $0 \mathrm{~V}$. Figure 5 shows the progress of the measured data.

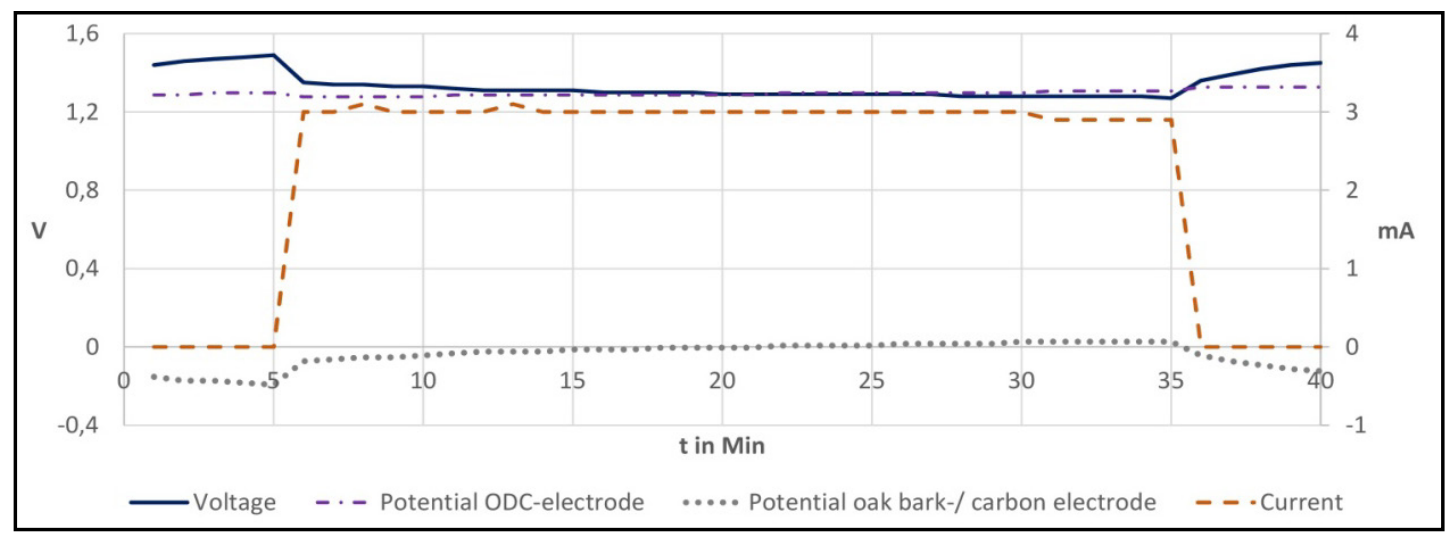

Figure 5. measured voltage, current and potential of the oak bark /oxygen battery 
Turning on the powerful electric motor with a current consumption of 20 to $25 \mathrm{~mA}$ leads to a considerably decrease of voltage over a period of 15 minutes. Likewise, the potential of the oak bark extract / graphite electrode increases drastically. Assuming that the electrochemical processes consume the tannin of the oak bark, the reaction equations can be formulated as exhibited in Figure 6 .

Batteries incorporating a sensitive electric motor can also be realized with iron(III)-sulfate solution (140 g iron(III)sulfate in $150 \mathrm{ml}$ water and $50 \mathrm{ml}$ sulfuric acid) and p-benzoquinone solution $(10 \mathrm{~g}$ p-benzoquinone in $50 \mathrm{ml}$ sulfuric acid and $50 \mathrm{ml}$ glacial acetic acid) at the cathodic side.

\subsection{Experiment: Organic Batteries with Ash Tree Bark}

Ash tree bark is used in natural medicine and homoeopathy for treating fever, rheumatism and ulcers.
For this, extracts are used internally as well as externally. However, there is no verified evidence for their effectiveness. Ash tree bark is rich in tannins, phenolic acids, polyphenols and triterpenes. Cumarin can also be found in the bark. We used cut and dried ash tree bark (Johannas Garten, https://joannasgarden.com/Eschenrindegeschnitten-100g, for e.g.).

Used equipment: Beakers $(600 \mathrm{~mL}$ and $100 \mathrm{~mL})$, terracotta pot, underside sealed with a rubber plug, carbon foil (approx. $3 \mathrm{~cm} \times 4 \mathrm{~cm}$ ), carbon/oxygen-electrode according to Oetken [20], silver/silverchloride electrode, sensitive electric motor (LemoSolar), powerful electric motor (Dreibein Lehrsysteme), 4 multimeters, magnetic stirrer with stirring bars, stand material, wires with crocodile clip.

Chemicals: Ash bark, sodium hydroxide solution $\mathrm{c}(\mathrm{NaOH})=1 \mathrm{~mol} / \mathrm{L}$, sulfuric acid $\mathrm{c}\left(\mathrm{H}_{2} \mathrm{SO}_{4}\right)=1 \mathrm{~mol} / \mathrm{L}$, glacial acetic acid, potassium chloride solution $(\mathrm{KCl})=$ $1 \mathrm{~mol} / \mathrm{L}$.

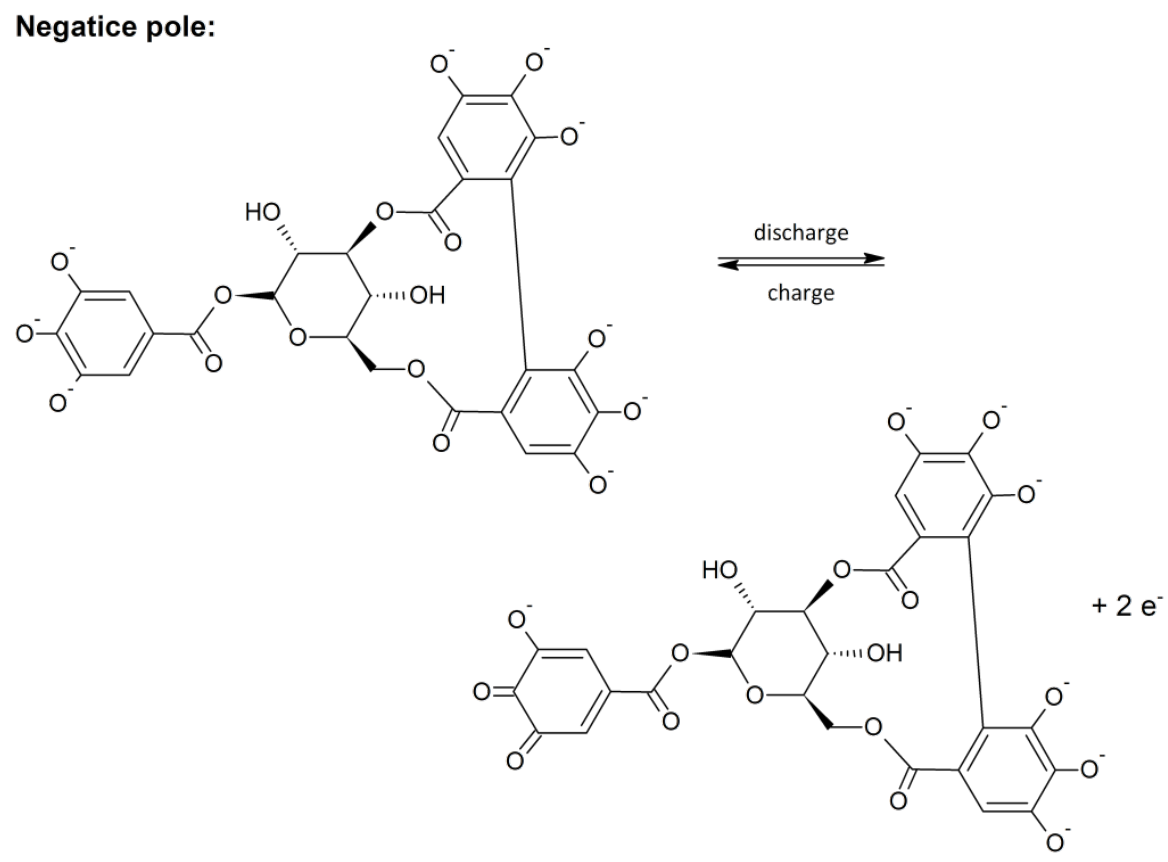

Positive pole:

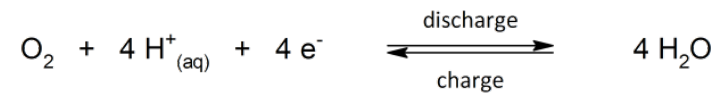

Figure 6. Electrode reaction of the oak bark / oxygen battery

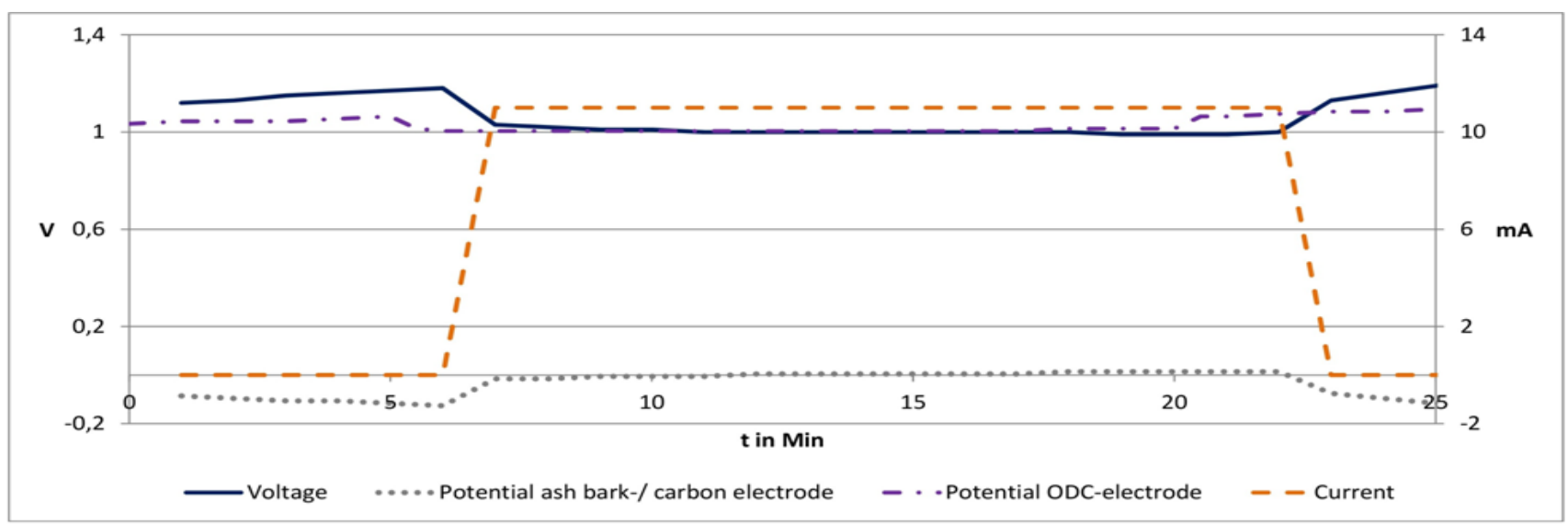

Figure 7. Measured voltage, current and potential of the ash bark /oxygen battery 
Procedure: The setup and the procedure is the same as in 3.1, but instead of the oak bark, ash bark is used. The ash bark is relatively small and the pieces can be left in the used solution. $30 \mathrm{~g}$ ash bark are heated in $200 \mathrm{~mL}$ of sodium hydroxide solution for 10 minutes slightly under its boiling point.

The voltage of the battery is at $1,18 \mathrm{~V}$ after 5 minutes. The resting potential of the carbon/oxygen-electrode is at $+1,06 \mathrm{~V}$ and the ash bark extract / graphite electrode at $-0,12 \mathrm{~V}$. A powerful electric motor can be operated with a current consumption of $11 \mathrm{~mA}$ with a small voltage drop. Figure 7 shows the progress of the measured data.
Ash bark contains tannins and polyphenols too, which are electrochemically processed (Figure 6).

\section{Batteries Using Peat}

Peat is the first step of the carbonization of organic material and stems normally from moss, degraded in moor and fen in relative acidic environment with little oxygen supply. Peat is used to improve garden ground and was used in its dried form as fuel. It can also be used in medicinal peat baths.

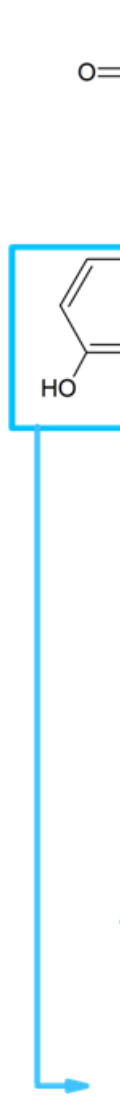<smiles>C=CC(=O)O</smiles>

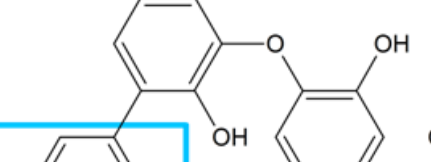

$\mathrm{OH}$

$\mathrm{HOH}$
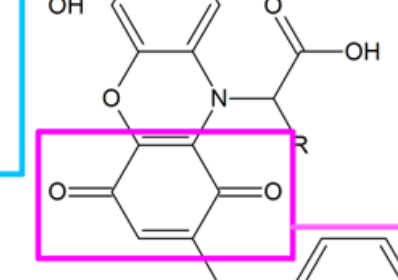

Negative pole:

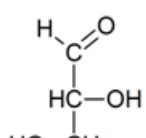

$\mathrm{HO}-\mathrm{CH}$

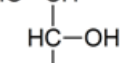

$\mathrm{HC}-\mathrm{OH}$<smiles>C=C(C(=O)O)C(C(=O)O)=C(C)O</smiles><smiles>[R]c1ccc(O)c(O)c1[OH+]</smiles>

1. Deprotonation<smiles>[R]c1ccc([O-])c([O-])[Z20]1C=C</smiles>

Positive pole:

Reduction
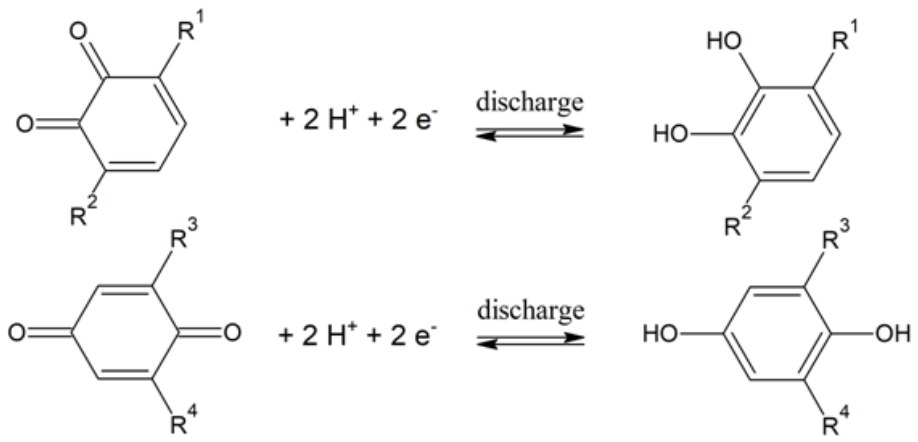

Figure 8. Representation of the humic acid molecule (blue box: oxidisable hydroxy groups; pink box: ketone groups) and the reaction scheme of the humic acid / humic acid battery 
Humic acids of the peat are awarded with medicinal properties. They are macromolecular compounds, exhibiting phenolic hydroxy as well as quinoid ketone groups (cf. Figure 8). Because of these structural elements, peat should be a viable substrate for organic batteries.

\subsection{Experiment: Organic Batteries with Peat and Oxygen}

Used equipment: Beakers (600 mL and $100 \mathrm{~mL})$, terracotta pot, underside sealed with a rubber plug, carbon foil (approx. $3 \mathrm{~cm} \times 4 \mathrm{~cm}$ ), carbon/oxygen-electrode according to Oetken [20], silver/silverchloride electrode, sensitive electric motor (LemoSolar), powerful electric motor (Dreibein Lehrsysteme), 4 multimeters, magnetic stirrer with stirring bars, stand material, wires with crocodile clip

Chemicals: Peat, sodium hydroxide solution $\mathrm{c}(\mathrm{NaOH})=1 \mathrm{~mol} / \mathrm{L}$, sulfuric acid $\mathrm{c}\left(\mathrm{H}_{2} \mathrm{SO}_{4}\right)=1 \mathrm{~mol} / \mathrm{L}$, glacial acetic acid, potassium chloride solution $(\mathrm{KCl})=$ $1 \mathrm{~mol} / \mathrm{L}$

Procedure: $20 \mathrm{~g}$ peat are heated in $20 \mathrm{~mL}$ sodium hydroxide solution. The carbon / oxygen electrode according to OETKEN [20] is put into the earthenware pot and the graphite foil into the peat suspension. The procedure follows as it is described in experiment 1 and shown in Figure 4.

The voltage of the battery is $0,87 \mathrm{~V}$. The potential of the carbon / oxygen electrode is at approximately $+1,15 \mathrm{~V}$ and the peat / graphite electrode at $+0,28 \mathrm{~V}$. In other experiments done with the peat / graphite electrode, a lower potential of down to $+0,12 \mathrm{~V}$ was determined. A sensitive electric motor was operated, with a current consumption of 2,3 $\mathrm{mA}$, but the voltage dropped to approx. $0,76 \mathrm{~V}$. The measured data are shown in Figure 9.

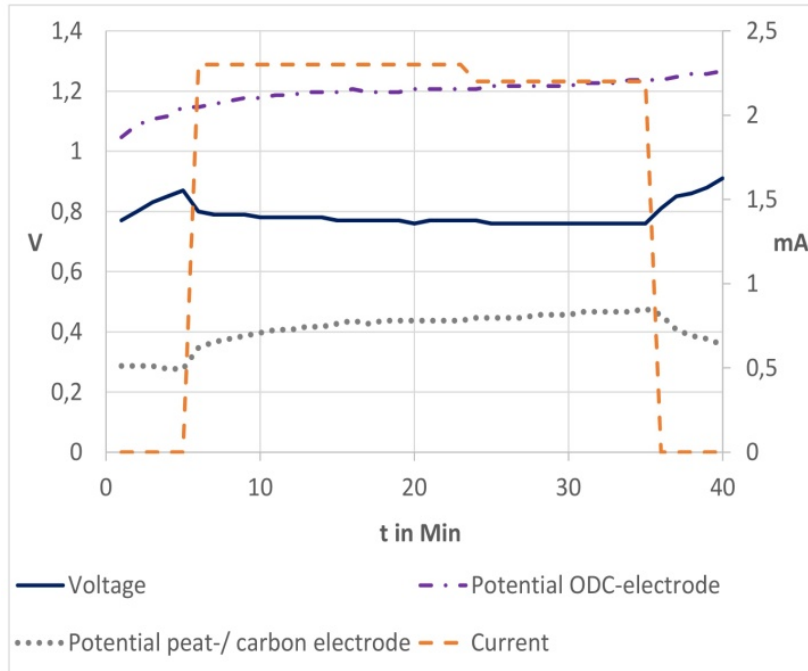

Figure 9. measured voltage, current and potential of the peat /oxygen battery

Using an iron(III)sulfate solution or $p$-benzoquinone solution as cathodic material, effective batteries can be constructed. Because of the quinoid ketone groups in the peat molecule, one could believe that a peat suspension in sulfuric acid can be used as a cathodic material, but experiments done in this direction yielded no satisfactory outcome.

\section{Organic Batteries with Humic Acids}

Humic acids themselves are the decomposition product of plant material. It is a macromolecular compound, which includes sugar and amino acid blocks. Especially polyphenols, carboxyl and ketone groups (cf. Figure 8). They can be found in humus, peat and lignite. Our experiments were conducted using the humic acids of the Pharmawerk Weinböhla, which are obtained out of selected lignite with specific properties [24]. It was purchased via the online pharmacy ApoRot. Humic acids are used for the treatment of diseases concerning the stomach and intestine of horses, dogs, cats and exotic birds. It is a black powder, which can bind unwanted products in the stomach.

\subsection{Experiment: Organic Batteries with Humic Acid and Oxygen}

Used equipment: Beakers (600 mL and $100 \mathrm{~mL})$, terracotta pot, underside sealed with a rubber plug, carbon foil (approx. $3 \mathrm{~cm} \times 4 \mathrm{~cm}$ ), carbon/oxygen-electrode according to Oetken [20], silver/silverchloride electrode, sensitive electric motor (LemoSolar), powerful electric motor (Dreibein Lehrsysteme), 4 multimeters, magnetic stirrer with stirring bars, stand material, wires with crocodile clip.

Chemicals: Humic acid, sodium hydroxide solution $\mathrm{c}(\mathrm{NaOH})=1 \mathrm{~mol} / \mathrm{L}$, sulfuric acid $\mathrm{c}\left(\mathrm{H}_{2} \mathrm{SO}_{4}\right)=1 \mathrm{~mol} / \mathrm{L}$, glacial acetic acid, potassium chloride solution $(\mathrm{KCl})=$ $1 \mathrm{~mol} / \mathrm{L}$.

Procedure: A suspension of $20 \mathrm{~g}$ humic acid in $200 \mathrm{~mL}$ of sodium hydroxide solution are heated to $70-80{ }^{\circ} \mathrm{C}$. To this suspension the carbon foil is added. The earthenware pot with sulfuric acid and the carbon / oxygen electrode according to OETKEN [20] are put into the beaker. The setup is similar to Figure 4.

The voltage of the battery is at $1,64 \mathrm{~V}$. The potential of the humic acid/carbon electrode is at $-0,52 \mathrm{~V}$ and the potential of the carbon / oxygen electrode at $+1,11 \mathrm{~V}$. A powerful electric motor worked, with a current consumption of $12,9 \mathrm{~mA}$, with a voltage drop to approx. 1,46 V. The potential of the humic acid / carbon electrode is stable at $-0,40 \mathrm{~V}$. The measured data are shown in Figure 10.

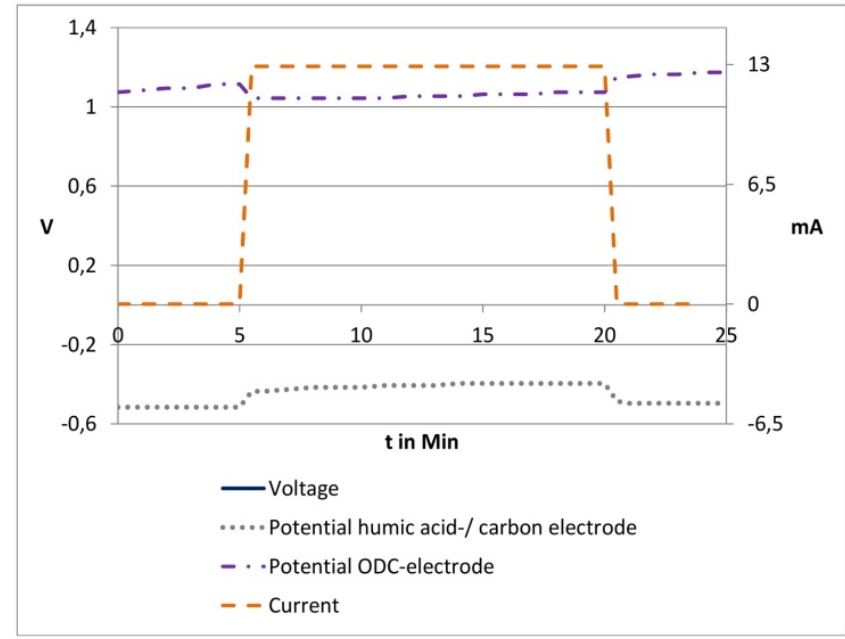

Figure 10. measured voltage, current and potential of the humic acid /oxygen battery 
The strong negative potential of the humic acid / carbon electrode led to the assumption, that a battery can be build with cerium(IV)sulfate as the cathodic material, achieving a voltage of the battery of $2 \mathrm{~V}$.

\subsection{Experiment: Humic Acid/Cerium(IV) Sulfate Battery}

Used equipment: Beakers (600 mL and $100 \mathrm{~mL})$, terracotta pot, underside sealed with a rubber plug, carbon foils (approx. $3 \mathrm{~cm} \times 4 \mathrm{~cm}$ ), silver/silverchloride electrode, sensitive electric motor (LemoSolar), powerful electric motor (Dreibein Lehrsysteme), 4 multimeters, magnetic stirrer with stirring bars, stand material, wires with crocodile clip.

Chemicals: Humic acid, cerium(IV)sulfate, sodium hydroxide solution $\mathrm{c}(\mathrm{NaOH})=1 \mathrm{~mol} / \mathrm{L}$, sulfuric acid $\mathrm{c}\left(\mathrm{H}_{2} \mathrm{SO}_{4}\right)=1 \mathrm{~mol} / \mathrm{L}$, glacial acetic acid, potassium chloride solution $(\mathrm{KCl})=1 \mathrm{~mol} / \mathrm{L}$.

Procedure: The experiment is conducted like experiment 5.1 with the slight modification, that instead of sulfuric acid a solution of $25 \mathrm{~g}$ cerium(IV)sulfate in 500 $\mathrm{mL}$ of sulfuric acid is used in the terracotta pot.

The voltage of the battery remarkably increased to $1,98 \mathrm{~V}$ in the course of 5 minutes. The potential of the humic acid / carbon electrode is at $-0,52 \mathrm{~V}$ and the cerium(IV)sulfate / carbon electrode at $+1,45 \mathrm{~V}$. After starting the powerful electric motor, the voltage drops slightly to $1,90 \mathrm{~V}$. The potential of the humic acid / carbon electrode increases to $-0,49 \mathrm{~V}$ and the cerium(IV)sulfate / carbon electrode drops to $+1,41 \mathrm{~V}$. After turning off the electric motor the voltage of the battery increases to 2,02 $\mathrm{V}$. The measured data are shown in Figure 11.
We already tried to construct a peat / peat battery, using peat in alkaline (anode) and acidic (cathode) environment. The idea behind this battery was to oxidize the phenolic hydroxyl groups on the one side and in turn to reduce the ketone groups on the other side. However, the experiment yielded no satifactory results. Now we hope for better results using pure humic acid instead of peat.

\subsection{Experiment: Humic Acid / Humic Acid Battery}

Used equipment: Beakers (600 mL and $100 \mathrm{~mL})$, terracotta pot, underside sealed with a rubber plug, carbon foils (approx. $3 \mathrm{~cm} \times 4 \mathrm{~cm}$ ), silver/silverchloride electrode, sensitive electric motor (LemoSolar), powerful electric motor (Dreibein Lehrsysteme), 4 multimeters, magnetic stirrer with stirring bars, stand material, wires with crocodile clip

Chemicals: Humic acid, sodium hydroxide solution $\mathrm{c}(\mathrm{NaOH})=1 \mathrm{~mol} / \mathrm{L}$, sulfuric acid $\mathrm{c}\left(\mathrm{H}_{2} \mathrm{SO}_{4}\right)=1 \mathrm{~mol} / \mathrm{L}$, glacial acetic acid, potassium chloride solution $(\mathrm{KCl})=$ $1 \mathrm{~mol} / \mathrm{L}$.

Procedure: A suspension of $20 \mathrm{~g}$ humic acid in $200 \mathrm{~mL}$ sodium hydroxide solution was heated to $75-80^{\circ} \mathrm{C}$. Likewise, a suspension of $10 \mathrm{~g}$ humic acid in sulfuric acid was prepared while heating. The latter was transfered to the earthenware pot and the carbon foil was put into it. The experiment was maintained at a temperature of $75^{\circ} \mathrm{C}$ while stirring the suspensions using a heatable magnetic stirrer. The electric circuit was set up as it is shown in Figure 4.

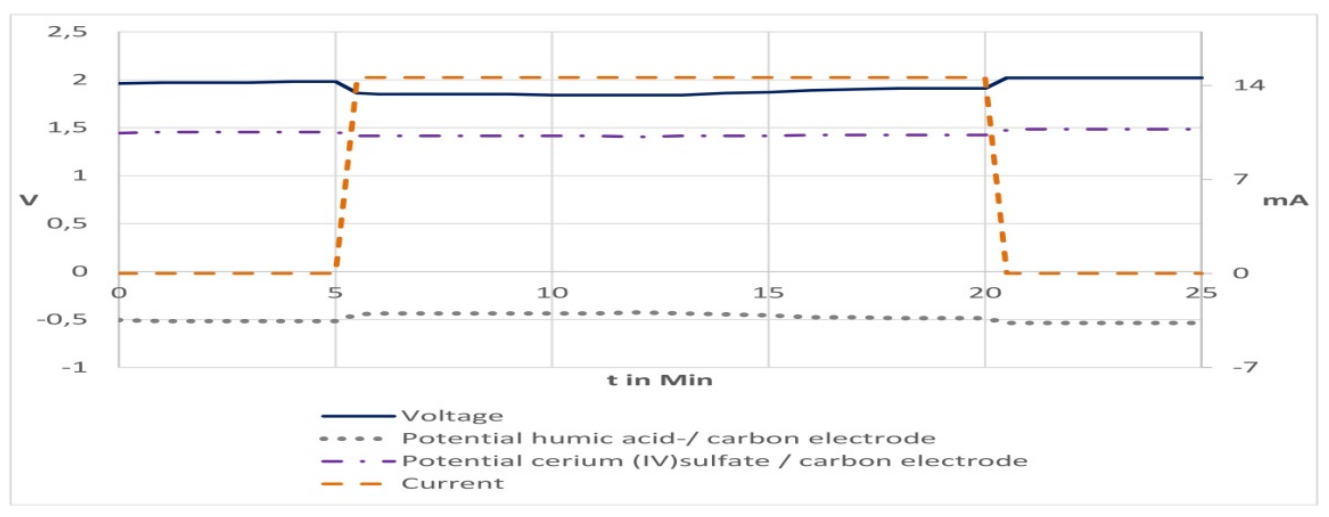

Figure 11. Measured voltage, current and potential of the humic acid / cerium(IV)sulfate battery

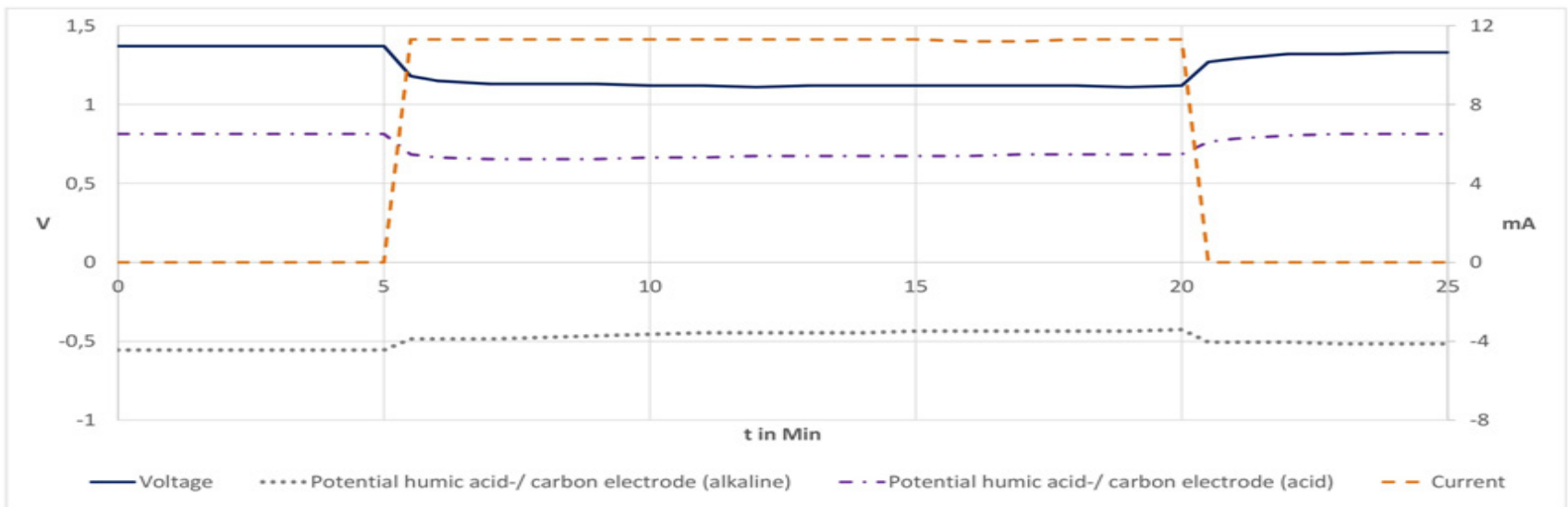

Figure 12. measured voltage, current and potential of the humic acid /humic acid battery 
The voltage of the battery is $1,37 \mathrm{~V}$. The potential of the humic acid / carbon electrode in alkaline solution is at $-0,56 \mathrm{~V}$ and the potential of the humic acid / carbon electrode in acidic solution at $+0,81 \mathrm{~V}$. The high difference in potentials encouraged us to introduce the powerful electric motor which was operated with a current consumption of $11,3 \mathrm{~mA}$. The voltage stays at approx. $1,12 \mathrm{~V}$ for the 15 minutes operating time.

The potential of the cathode drops slightly to $+0,65 \mathrm{~V}$ but recovers in course of the operating time to $+0,68 \mathrm{~V}$. The potential of the anode is at $-0,43 \mathrm{~V}$. After turning off the electric motor, the voltage of the battery increases to $1,33 \mathrm{~V}$. The potential of the electrode in acidic environment increases to $+0,81 \mathrm{~V}$ and the potential of the electrode in alkaline environment drops to $-0,52 \mathrm{~V}$. The measured data are shown in Figure 12. The reaction scheme (cf. Figure 8) shows our assumptions for the reactions taking place in the humic acid / humic acid battery, proving itself to be a surprisingly good electrochemical cell.

\section{Outlook}

The battery using tannin exhibits rechargeabilty, which was determined via cyclic voltammetry. The rechargeability of the used redox systems is a prerequisite for the application of the Redox-Flow-Batteries. Our task at hand is to determine, whether the redox systems described herein are eligible for the use at school as model experiments for the demonstration of the operating principle of Redox-Flow-Batteries.

\section{Acknowledgements}

We thank the "Fonds der chemischen Industrie" for funding this research project.

\section{References}

[1] Bührke, T., Wengenmeyer, R., Erneuerbare Energien Konzepte für die Energiewende, Weinheim, 2012

[2] Lambertz, J., Schiffer, H.-W., Serdarusic, I., Voß, H., "Flexibilität von Kohle- und Gaskraftwerken zum Ausgleich von Nachfrageund Einspeiseschwakungen”, Energiewirtschaftliche Tagesfragen, 62 (7). 16-20. 2012.

[3] Kaltschmitt, M., Streicher, W., Wiese, A., Erneuerbare Energien - Systemtechnik, Wirtschaftlichkeit, Umweltaspekte, Berlin-Heidelberg, 2006.

[4] Sterner, M., Stadler, I., Energiespeicherung - Bedarf, Technologien, Integration, Berlin-Heidelberg, 2014, 282-290.

[5] Kurzweil, P., Dietlmeier, O. K., Elektrochemische Speicher Superkondensatoren, Batterien, Elektrolyse-Wasserstoff, Rechtliche Grundlagen, Wiesbaden, 2015, 343-346.
[6] Weber, A. Z., Mench, M. M., Meyers, J. P., Ross, P.N., Gostick, J. T., Liu, Q., Redox flow batteries: a review., Appl Electrochem 41, 1137-1164. 2011.

[7] Bartolozzi, M.; Development of Redox Flow Batteries. A Historical Bibliography, Journal of Power Sources 27, 219-234. 1989.

[8] Gillhuber, A., Eine Woche Strom für 40 Häuser?, 2014. Avaible: http://www.elektroniknet.de/power/energiespeicher/artikel/111844/.

[9] Kempkens, W., Elektroautos mit Redox-Flow-Batterie können wirklich fahren, 2016. Avaible http://www.ingenieur.de/Themen/Automobil/Elektroautos-RedoxFlow-Batterie-koennen-wirklich-fahren.

[10] Huskinson, B., Nawar, S., Gerhardt, M. R., Aziz, M., "Novel Quinone-Based Couples for Flow-Batteries.", ECS Transactions, 57 (7). 101-105. 2013.

[11] Huskinson, B., Marshak, M.P., Changwon, S., Süleyman, E., Gerhardt, M. R., Galvin, C. J., Chen, X., Aspuru-Guzik, A., Gordon, R. G., Aziz, M., "A metal-free organic - inorganic aqueous flow-battery.", Nature, 505. 195-198. 2014.

[12] Yang, B., Hoober-Burkhardt, L., Wang, F., Prakash, G. K. S., Narayanan, S. R., "An Inexpensive Aqueous Flow Battery for Large-Scale Electrical Energy Storage Based on Water-Soluble Organic Redox Couples.”, ESC, 161(p). 1371-A1380. 2014.

[13] Janoschka, T., Martin, N., Martin, U., Friebe, C., Morgenstern, S., Hiller, H., Hager, M., Schubert, U., An aqueous, polymer-based redox-flow battery using non-corrosive, safe, and low-cost materials, Nature 527, 8-9. 2015.

[14] Rosenberg, D., Pansegrau, S., Wachholz, M., Köppen, A., Busker, M., Jansen, W. (2018): Organic Redox-Flow Batteries Using Hair Dyes and Pharmaceuticals, WJCE 6 (1), 63-71.

[15] Rosenberg, D., Pansegrau, S., Busker, M., Jansen, W., Energiespeicherung in organischen Redox-Flow-Battries mit dem roten Farbstoff in Henna. Nachrichten aus der Chemie 65 (2), 167-171. 2017.

[16] Rosenberg, D., Rehling, A., Busker, M., Jansen, W., Organische Batterien mit Gallussäure, Pyrogallol und grünem Tee. Praxis der Naturwissenschaften-Chemie in der Schule 65 (6), 22-27. 2016.

[17] Rosenberg, D., Wachholz, M., Busker, M., Jansen, W., Organische Batterien mit Alizarin - Schulexperimente zur Demonstration von Flow-Batteries mit dem Farbstoff der Krappwurzel. Praxis der Naturwissenschaften-Chemie in der Schule 65 (3), 14-19. 2016.

[18] Rosenberg, D., Koring, D., Pansegrau, S., Rehling, A., Busker, M., Jansen, W., Redox-Flow-Batteries - Organische Batterien mit Farbstoffen, Mathmatisch-Naturwissenschaftlicher Unterricht 71 (1), 29-36. 2018.

[19] Rosenberg, D., Rehling, A., Ernst, D., Busker, M., Jansen, W., Organische Batterien mit Phloroglucin und Vanillin. Praxis der Naturwissenschaften-Chemie in der Schule 66 (2), 9-14. 2017.

[20] Klaus, M., Hasselmann, M., Rubner, I., Mößner, B., Oetken, M., Metall-Luft-Batterien mit einer neuartigen Kohleelektrode. Chemkon 21 (2). 65-71. 2014.

[21] Otto, T., Pöhls, C., Busker, M., Jansen, W., Chlor-AlkaliElektrolyse mit der Sauerstoffverzehrkathode, Praxis der Naturwissenschaften-Chemie in der Schule 8/64. 36-39. 2015.

[22] Jansen, W., Kenn, M., Flintjer, B., Peper, R.: Elektrochemie Wechselwirkung zwischen stofflicher Veränderung und elektrischer Energie, Aulis Kolleg Chemie, Köln. 1994.

[23] Rosenberg, D., Behnisch, M., Pansegrau, S., Busker, M., Jansen, W., Speicherung elektrischer Energie mit neuartigen, organischen Batterien - einfache Schulexperimente zur Demonstration von Flow-Batteries. Praxis der Naturwissenschaften-Chemie in der Schule 65 (4), 36-42. 2016.

[24] Pharmawerk Weinböhla: Huminsäuren WH67® Natürliche Gesundheit, booklet. 